\title{
Effect of Aqueous Extract of Punica granatum Peel on the Oxidative Damage Induced by Lead Intoxication in Rats
}

\author{
Nahed F. Zaglool ${ }^{1}$, Shahenaz M.H. Hassan ${ }^{2 *}$ and Sanaa A. El-shamy ${ }^{3}$ \\ ${ }^{1}$ Biochemistry Department, Animal Health Research Institute, Alexandria \\ ${ }^{2}$ Clinical Pathology Department, Animal Health Research Institute, Alexandria \\ ${ }^{3}$ Pathology Department, Animal Health Research Institute, Alexandria
}

Article History: Received: 5/2/2017 Received in revised form: 12/4/2017 Accepted: 1/6/2017

\begin{abstract}
The present investigation aimed to evaluate the effect of aqueous extract of local pomegranate peel on the oxidative damage induced by lead intoxication in rats. Forty-eight female Albino rats were divided into four equal groups. Group (1) kept as a control group, while Group (2) was fed on $1000 \mathrm{ppm}$ lead acetate in drinking water. Group (3) received $1000 \mathrm{ppm}$ lead acetate in drinking water plus $1 \mathrm{~mL}$ of distilled water containing $43 \mathrm{mg} / \mathrm{rat}$ of pomegranate peel aqueous extract via gastric intubation and Group (4) received $1 \mathrm{~mL}$ of distilled water containing $43 \mathrm{mg} / \mathrm{rat}$ of Pomegranate peel aqueous extract via gastric intubation. All rats were treated with the respective regime daily for five weeks. Administrations of lead acetate for 5 weeks caused significant decrease of total proteins, globulins $(\alpha, \beta \& \gamma)$, triiodothyronine (T3) and thyroxine hormone (T4) with significant increase of the urea, creatinine, aspartate aminotransferase, alanine aminotransferase, alkaline phosphatase, lead residue in liver and lipid peroxidase. Mild degenerative and necrobiotic changes in liver and kidney were detected histopathologically. Administration of pomegranate peel extract revealed minor ameliorative effect on serum proteins, aminotransferases and urea levels. Treating rats with both of lead acetate and Punica granatum peel aqueous extract for 5 weeks revealed focal hepatic necrosis, hypercellularity of renal glomeruli and degeneration in the epithelial cells lining of renal tubules. Administration of aqueous extract of Punica granatum peel for 5 weeks to healthy rats induced congestion of central vein of liver and degeneration in the epithelial cells lining of renal tubules. This study figure out that administration of Punica granatum peel aqueous extract had a mild deleterious effect on healthy rats with a slight improvement on the oxidative damage induced by lead intoxication in rats.
\end{abstract}

Keywords: Lead toxicity, Punica granatum, Biochemical, Histopathology.

\section{Introduction}

The lead in the biosphere is 1000 to 10,000 times above its natural level that reached the body by ingestion and/or inhalation [1]. The prolonged exposure to even low amounts can induce renal and hepatic disorders and toxic effects in human and animals due to its slowly excretion and cumulative property [2-5]. Ingested lead is absorbed and conjugated in the liver then partially excreted in urine, while the rest usually accumulated in different organs causing molecular and cellular changes. The lead side effect (biochemical and histological alternations) is long lasting even after its levels is diminished [6,7]. Ibrahim et al. [8] reported a significant increase in aspartate aminotransferase AST and alanine aminotransferase ALT activity with a significant decrease of serum thyroxine T4, triiodothyronine $\mathrm{T} 3$ total proteins and albumin levels in lead acetate intoxicated rat. In spite of the exact mechanism of lead toxicity is not clear, there is prove that lead can induce generation of reactive oxygen species (ROS) which could induce inhibition of antioxidants activities that may cause pathological disorders in the body organs $[9,10]$. Lipid peroxidation was increased by lead intoxication [11]. Antioxidants from natural sources have become common for medical and food applications than synthesized antioxidants that preferred by consumers. The pomegranate peel has higher antioxidant capacity than its pulp and seed [12]. In hyperlipidemic rats, pomegranate peel has a

*Corresponding author email: (eshahenaz@yahoo.com), Clinical Pathology Department, Animal Health 112 Research Institute, Alexandria 
significant improvement on antioxidant enzyme activities [13]. Khalil [14] reported that $P$. granatum peels aqueous extract has an antioxidant activity which could decrease the harmful effect of acetaminophen on liver. On the other hand, Hasan et al. [15] mentioned that the administration of pomegranate peel water extract with lead acetate induced hypocellurity and increased adiposity in rats' bone marrow. This conflict paid a concern in probing further into its affectivity, therefore the present study was aimed to evaluate the effect of aqueous extract of local pomegranate peel on the oxidative damage induced by lead intoxication in rats.

\section{Material and Methods}

\section{Plant extraction}

The pomegranate peel purchased from local market at Alexandria city, Egypt, was washed, cut into small pieces and left to dry in air and the complete dryness occurred in an oven at $50^{\circ} \mathrm{C}$. The dried peels were ground to fine powder. The pomegranate peel extract was obtained by boiling $3 \mathrm{gm}$ of pomegranate peel powder with $200 \mathrm{ml}$ distilled water and then filtered after cooling. The filtrate was dried at $40-45^{\circ} \mathrm{C}$ in the incubator and kept dry until used [16].

\section{Animals and experimental design}

The present study was conducted on fortyeight clinically healthy female Albino rats, weighing 80-100g. All rats were housed in clean metal cages, fed on pellet diet and water ad-labium. They were acclimatized for 2 weeks prior to the beginning of the experiment. Rats were divided into four equal groups as the following: Group (1) kept as a control group and group (2) received 1000 ppm lead acetate (lead acetate trihydrate $99 \%$, El-Gmhoria $\mathrm{Co}^{\circledR}$ ) in drinking water according to Suradkar et al. [17]. Group (3) received $1000 \mathrm{ppm}$ lead acetate in drinking water plus 1 $\mathrm{mL}$ of distilled water containing $43 \mathrm{mg} / \mathrm{rat}$ of pomegranate peel aqueous extract via gastric intubation [16], while, Group (4) received 1 $\mathrm{mL}$ of distilled water containing $43 \mathrm{mg} / \mathrm{rat}$ of pomegranate peel aqueous extract via gastric intubation. All rats were treated with the respective regime daily for five weeks. Blood and tissue samples (liver and kidney) were collected from all rats at the end of the experiment.

\section{Serum biochemical analysis}

Blood samples were collected from retroorbital venous plexus of rats and then the serum separated for biochemical analysis. Serum total proteins [18] and albumin [19] were determined using kit (Diamond Diagnostics), while serum globulins and Albumin/Globulins ratio (A/G ratio) were calculated mathematically. $\alpha, \beta$ and $\gamma$ Ig $[20,21]$, serum alanin aminotransferase (ALT), aspartate aminotransferase (AST) activities [22], serum alkaline phosphatase, (ALP) activity (kits of bioMerieux/ France) [23], serum urea level (kits bioMerieux) [24], serum creatinine (kits bioMerieux) [25], serum cholesterol [26] and Lipid peroxidation (LPO) (kits (Biodiaguostic) ${ }^{\circledR}$ ) [27] were determined. Serum Lead level was estimated using an atomic absorption spectrophotometer/flame [28]. The concentrations of T3 and T4 were assayed according to the method described by Nussey and Whitehead [29] using enzymelinked immunosorbent assay (ELISA) kits (Microwell T3, T4 kits; Synthron Bioresearch, Inc, USA). Serum calcium [30] and phosphorous [31] were determined using kits $\left(\right.$ BioMed) ${ }^{\circledR}$.

\section{Determination of lead residues in liver tissues}

A wet digestion procedure was used [32] by adding nitric and perchloric acids in a ratio of 5:1 for each one gram of tissue in a Kjeldahl flask. The mixture was heated on a hot plate till became colorless solution and then diluted with deionized water up to $50 \mathrm{~mL}$. Blank was treated in the same manner as samples. Atomic absorption spectrophotometric procedure was used for the evaluation of lead as qualified in Perkin Elmer catalogue of atomic absorption model 2380, U.S.A (1982). Atomic absorption with a single slot burner head was used at wave length of $248.3 \mathrm{~nm}$ for lead.

\section{Histopathological examinations}

All rats were sacrificed at the end of experiment and subjected to careful post mortem examination. Tissue specimens were collected from liver and kidney. The specimens were immediately fixed in $10 \%$ neutral buffered formalin and then processed, 
stained with Heamatoxylin and Eosin and microscopically examined [33].

\section{Statistical analysis}

All data were demonstrated as means \pm SD. One-way analysis of variance (One-way ANOVA) followed by Least Significant Difference (LSD) test was used to determine the differences among means of the investigated groups (SPSS version 16.0 for windows, Statistical Package for the Social Sciences Inc, Chicago, Illinois). The differences were considered to be statistically significant at $\mathrm{P} \leq 0.05$.

Table 1: Biochemical parameters of the four investigated groups (mean \pm SD)

\begin{tabular}{|c|c|c|c|c|}
\hline Parameters & Group1 & Group2 & Group3 & Group 4 \\
\hline Total protein $(\mathrm{g} / 100 \mathrm{~mL})$ & $4.31 \pm 0.15^{\mathrm{a}}$ & $2.61 \pm 0.16^{\mathrm{d}}$ & $3.61 \pm 0.11^{b}$ & $3.15 \pm 0.17^{\mathrm{c}}$ \\
\hline Albumin $(\mathrm{g} / 100 \mathrm{~mL})$ & $2.48 \pm 0.14^{\mathrm{a}}$ & $1.73 \pm 0.16^{\mathrm{d}}$ & $2.11 \pm 0.12^{\mathrm{b}}$ & $1.96 \pm 0.11^{\mathrm{c}}$ \\
\hline Globulin (g/100 mL) & $1.83 \pm 0.19^{\mathrm{a}}$ & $0.88 \pm 0.013^{\mathrm{d}}$ & $1.50 \pm 0.105^{\mathrm{b}}$ & $1.19 \pm 0.08^{\mathrm{c}}$ \\
\hline $\mathrm{A} / \mathrm{G}$ ratio & $1.40 \pm 0.03^{\mathrm{c}}$ & $1.96 \pm 0.02^{\mathrm{a}}$ & $1.40 \pm 0.02^{\mathrm{c}}$ & $1.60 \pm 0.04^{\mathrm{b}}$ \\
\hline$\alpha$ Globulin $(\mathrm{g} / 100 \mathrm{~mL})$ & $0.56 \pm 0.02^{\mathrm{a}}$ & $0.28 \pm 0.001^{\mathrm{d}}$ & $0.48 \pm 0.03^{\mathrm{b}}$ & $0.35 \pm 0.03^{\mathrm{c}}$ \\
\hline$\beta$ Globulin $(\mathrm{g} / 100 \mathrm{~mL})$ & $0.43 \pm 0.01^{\mathrm{a}}$ & $0.27 \pm 0.01^{\mathrm{c}}$ & $0.44 \pm 0.05^{\mathrm{a}}$ & $0.35 \pm 0.02^{b}$ \\
\hline$\gamma$ Globulin $(\mathrm{g} / 100 \mathrm{~mL})$ & $0.84 \pm 0.01^{\mathrm{a}}$ & $0.33 \pm 0.03^{\mathrm{d}}$ & $0.58 \pm 0.06^{\mathrm{b}}$ & $0.49 \pm 0.02^{c}$ \\
\hline Cholesterol(mg/100 mL) & $53.20 \pm 1.20^{\mathrm{d}}$ & $120.71 \pm 2.00^{\mathrm{a}}$ & $76.70 \pm 1.00^{\mathrm{c}}$ & $88.70 \pm 0.80^{\mathrm{b}}$ \\
\hline Urea $(\mathrm{mg} / 100 \mathrm{~mL})$ & $46.10 \pm 2.90^{\mathrm{b}}$ & $52.60 \pm 0.05^{\mathrm{a}}$ & $47.10 \pm 2.60^{\mathrm{b}}$ & $45.80 \pm 2.60^{\mathrm{b}}$ \\
\hline Creatinine $(\mathrm{mg} / 100 \mathrm{~mL})$ & $0.37 \pm 0.01^{\mathrm{d}}$ & $0.91 \pm 0.03^{\mathrm{a}}$ & $0.55 \pm 0.06^{\mathrm{c}}$ & $0.72 \pm 0.02^{\mathrm{b}}$ \\
\hline${ }^{1} \mathrm{AST}(\mu / \mathrm{L})$ & $117.00 \pm 4.60^{\mathrm{d}}$ & $225.20 \pm 4.90^{\mathrm{a}}$ & $168.40 \pm 2.07^{\mathrm{c}}$ & $195.40 \pm 3.8^{\mathrm{b}}$ \\
\hline${ }^{2} \mathrm{ALT}(\mu / \mathrm{L})$ & $35.50 \pm 3.50^{\mathrm{d}}$ & $66.20 \pm 3.10^{\mathrm{a}}$ & $47.80 \pm 1.60^{c}$ & $52.00 \pm 2.50^{\mathrm{b}}$ \\
\hline${ }^{3} \mathrm{ALP}(\mu / \mathrm{L})$ & $113.60 \pm 4.03^{\mathrm{d}}$ & $232.80 \pm 8.50^{\mathrm{a}}$ & $185.47 \pm 4.50^{\mathrm{c}}$ & $199.84 \pm 3.30^{\mathrm{b}}$ \\
\hline Lipid peroxidation $(\mathrm{mmoL} / \mathrm{mL})$ & $0.39 \pm 0.03^{c}$ & $0.91 \pm 0.03^{\mathrm{a}}$ & $0.41 \pm 0.03^{\mathrm{c}}$ & $0.47 \pm 0.02^{\mathrm{b}}$ \\
\hline${ }^{4} \mathrm{~T} 3(\mathrm{mmoL} / \mathrm{L})$ & $1.22 \pm 0.16^{\mathrm{a}}$ & $0.64 \pm 0.11^{\mathrm{c}}$ & $0.93 \pm 0.04^{\mathrm{b}}$ & $0.81 \pm 0.04^{\mathrm{b}}$ \\
\hline${ }^{5} \mathrm{~T} 4(\mathrm{mmoL} / \mathrm{L})$ & $83.90 \pm 1.24^{\mathrm{a}}$ & $36.50 \pm 0.83^{\mathrm{d}}$ & $42.08 \pm 1.04^{\mathrm{c}}$ & $40.51 \pm 1.22^{\mathrm{b}}$ \\
\hline Calcium (mg/100 mL) & $6.55 \pm 0.14^{\mathrm{c}}$ & $7.57 \pm 0.15^{\mathrm{a}}$ & $7.34 \pm 0.09^{\mathrm{b}}$ & $6.28 \pm 0.09^{\mathrm{d}}$ \\
\hline Phosphorus (mg/100 mL) & $4.43 \pm 0.12^{\mathrm{b}}$ & $5.19 \pm 0.07^{\mathrm{a}}$ & $5.29 \pm 0.07^{\mathrm{a}}$ & $4.32 \pm 0.08^{\mathrm{b}}$ \\
\hline Lead $(\mu \mathrm{g} / 100 \mathrm{~mL})$ in serum & $1.04 \pm 0.01^{\mathrm{d}}$ & $35.66 \pm 0.29^{a}$ & $9.81 \pm 0.07^{\mathrm{c}}$ & $14.96 \pm 0.19^{\mathrm{b}}$ \\
\hline Lead $(\mu \mathrm{g} / \mathrm{g})$ in liver & $0.44 \pm 0.01^{\mathrm{d}}$ & $1.86 \pm 0.07^{\mathrm{a}}$ & $1.20 \pm 0.08^{c}$ & $1.44 \pm 0.07^{\mathrm{b}}$ \\
\hline
\end{tabular}

\section{Results and Discussion}

In the present study, administration of $1000 \mathrm{ppm}$ of lead via drinking water for 5 weeks revealed a significant increase in serum activities of AST and ALT (Table 1) which might be due to increase permeability of the cell membrane or damage of the cell membrane of hepatocytes caused by lead intoxication. Our results are in accordance with that reported by Shalan et al. [34]. A significant increase in serum ALP activity was observed in lead acetate treated group compared to the control group. This might be due to the hazard effect of lead on liver, kidney and bone resulting in liberation of ALP $[17,34,35]$. The histopathological findings of lead acetate-intoxicated rats revealed severe vacuolar degeneration in hepatocytes (Figure 1a), congestion of hepatic sinusoids. (Figure 1b), focal hepatic necroses mostly in portal areas (Figure 1c) and congested blood vessels among necrotic hepatocytes (Figure 1d). These changes were comparable to those stated by El-Neweshy and El-Sayed [4]. In consistence with our results, Dewanjee et al. [5], ElSokary [36], and El-Sayed et al. [37] reported that, the liver of lead-treated rats showed degenerative changes and focal necrosis of hepatocytes. Lead toxicity induced swelling of hepatocyte, vacuolization, focal necrosis, and pyknotic nuclei and dilation of central vein [38]. 

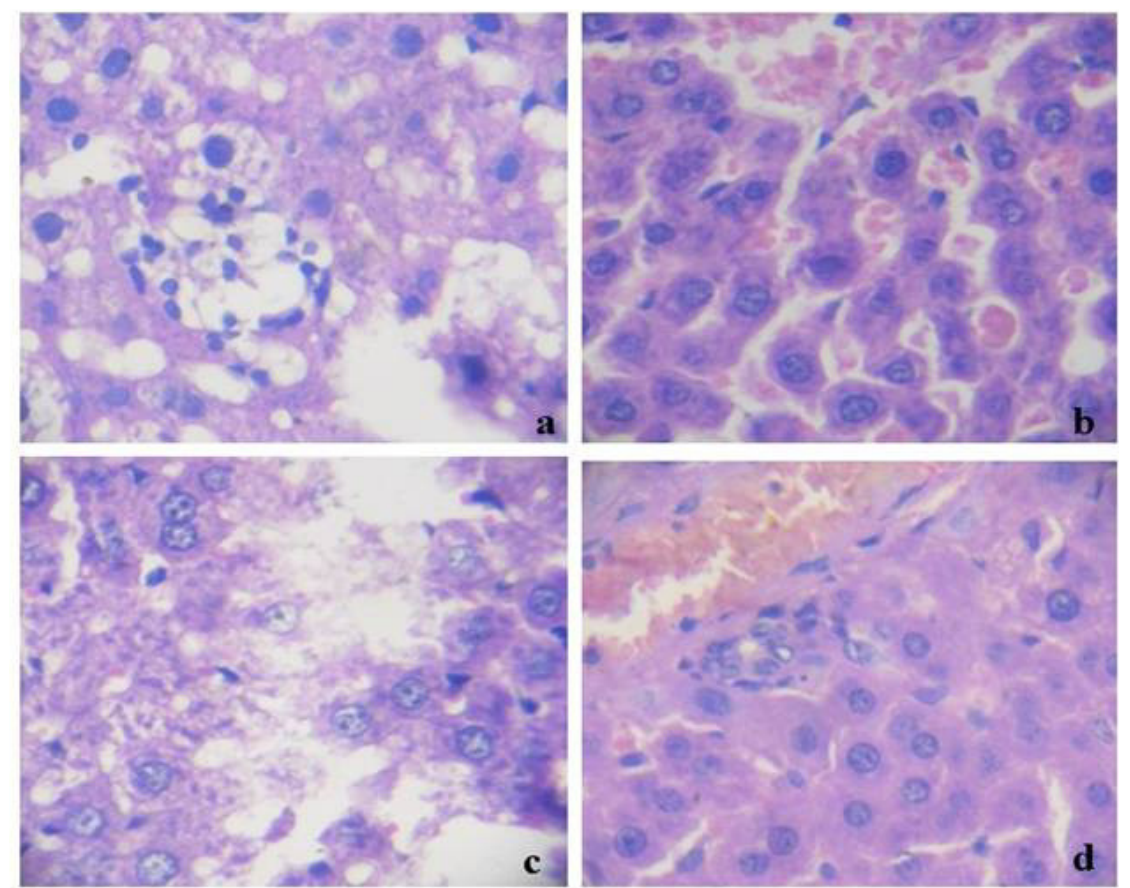

Figure 1: Liver section of rat treated with lead acetate stained with H\&E showed (a) Diffuse vacuolar degeneration of hepatocytes X400. (b) Congestion of hepatic sinusoids X400. (c) Focal area of necrosis X400. (d) Congested blood vessels among necrotic hepatocytes X400.

The significant reduction in serum total proteins of lead treated group may be attributable to the hypoalbuminemia that caused by a reduction of albumin synthesis from damaged hepatocytes or lead binding with albumin [17]. There was significant decrease in serum globulins $(\alpha, \beta$ and $\gamma$ globulin) of lead treated rats (Table 1), which are in agreement with Zaki et al. [39], who reported that high pollution with lead in animals and birds caused immunological suppression. The current results also demonstrated a significant increase in serum levels of calcium and phosphorus of lead treated rats (Table 1), which could be attributed to the affinity of lead to organic osteoid substance of bone rather than its mineral components [40]. This finding was disagreement with Ikechukwu et al. [41] and Mogwasi et al. [42] who reported a negative correlation of the mean levels of lead with calcium and phosphorus. Lead toxicity is attributed to its high affinity toward calmodulin [43]. Calmodulin have four $\mathrm{Ca}^{2+}$ binding sites, where lead can join to additional second class of calmodulin binding sites [44]. Shier et al. [45] reported that this induced an altered effect on the activation of protein kinases, which move phosphates groups from ATP molecules to protein substrates, changes the format of the substrate and converts them from inactive to active forms. This modify various processes such as further activating enzymes, changing membrane permeability, raising synthesis of certain proteins, inhibiting or stimulating metabolic pathways and initiating secretion of hormones and other substances. The serum levels of T3 and T4 showed significantly decrease in lead acetate treated group compared with the other groups (Table 1). This finding was in agreement with Pekcici et al. [46] who reported that high levels of lead in blood might affect thyroid. On the other hand, Singh et al. [47] mentioned that no significant changes were observed in T3 and T4 levels (human) as compared with the control group. There was a significant improvement in T3 and T4 level in lead + pom. group compared with the lead group. This result is in accordance with Arrak [48], who reported a dose-dependent improvement of the deleterious effect of lead acetate on rats thyroid that treated by ellagic acid from Pomegranate and resulting in a significant improvement of their functions activities. 

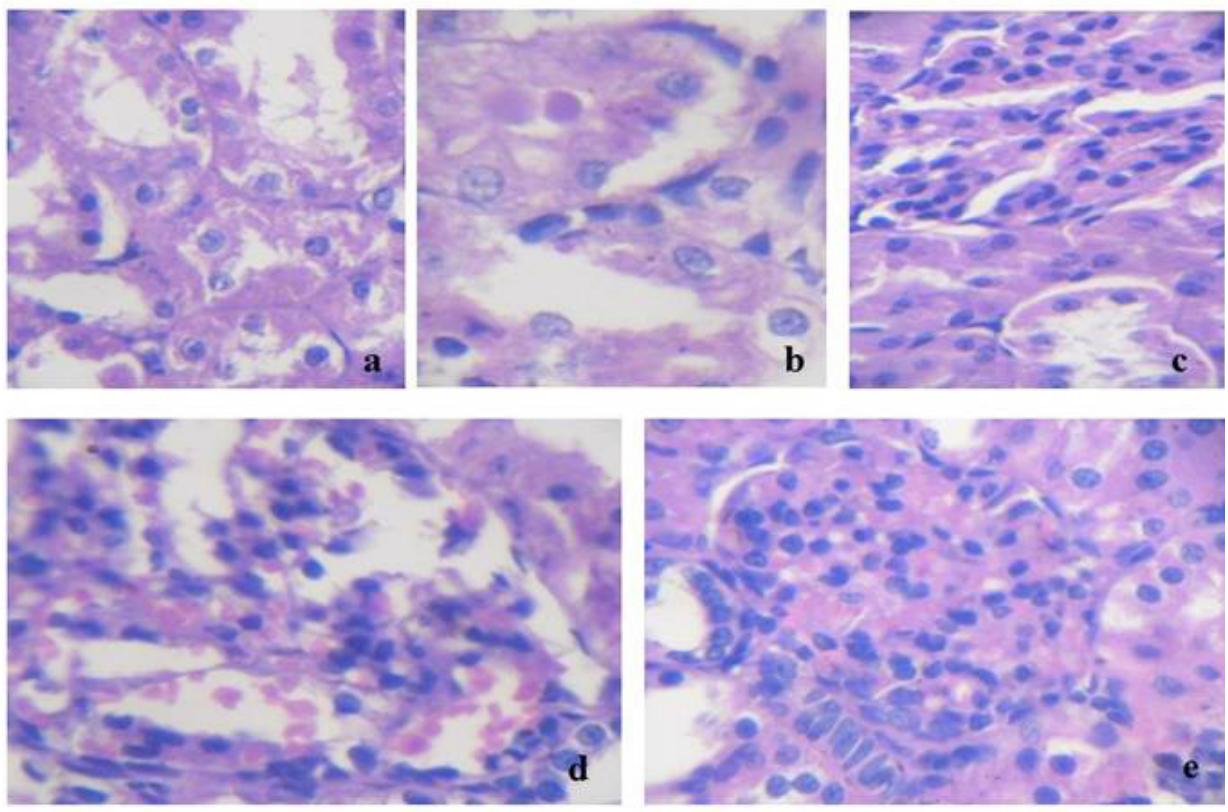

Figure 2: Kidney section of rat treated by lead acetate stained with $H \& E$ showed (a\&b) Necrosis of renal tubules epithelium. Dilation of renal tubule with the presence of hyaline tubular cast X400. (c) Vacuolar endothelium in the glomerular tuft with tubular degeneration in the epithelial cells lining the renal tubule X400. (d\&e) Hyperemic glmerulie tuft and glomerulus hypercellularity X400.

Urea and creatinine elevations of lead treated group might be due to impairment of kidney function and considered as functional evidence of nephrotoxicity [49]. In this context, histopathological alteration in kidney of lead intoxicated rats showed necrosis in the epithelium of renal tubules and renal tubule dilation with hyaline tubular cast formation (Figure 2a\&b), vacuolation of endothelium in the glomerular tuft with degeneration in the epithelial cells lining the renal tubule (Figure 2c), glomerulus's hypercellularity and hyperemic glomeruli tuft (Figure 2d\&e). These results were similar to that detected by ElSayed et al. [37] and El-Nekeety et al. [50], who reported that rats treated with lead acetate exhibited vacuolar and cloudy swelling in renal tubule epithelial cells, tubular dilation, interstitial inflammatory cells with hemorrhage and glomerulus's hypercellularity, which attributed to partial excretion of lead through the kidney [6,7] and oxidative damage of lead induced generation of reactive oxygen species [9]. In the same scene, the result of serum lipid peroxidase showed a significant increase of lead acetate treated group compared to the control group and lead + pom. group (Table 1). This result agreed with Upasani et al. [11] who stated that lead intoxication caused increase in the lipid peroxidation. Pomegranate peel extract suppressed lipid peroxidation $[47,51,52] . \quad$ In this context, pomegranate antioxidant activity is attributed to its polyphenolic capacity [53], which acts as an electron donor in elimination of free radicals [54].

Rats treated with pomegranate peel aqueous extract (43 mg/rat) for 5 weeks showed a significant increase $(\mathrm{p} \leq 0.05)$ in serum AST, ALT and ALP (Table 1). This result was in agreement with Khalil [55] who reported that repeated over dose of pomegranate peel extract showed a significant increase of serum AST, ALT and ALP. On the other hand, Abd Elmoneim et al. [7] detected that pomegranate has no significant effects on ALT, AST but it caused a reduction in alkaline phosphatase when administered in the form of juice or peel extracts. In this context, administration of Punica granatum peel extract for 5 weeks in healthy female albino rats revealed presence of apoptotic cells in 
hepatic parenchyma (Figure 3a), sinusoidal dilatation and pyknotic nuclei in necrotic hepatocytes. Congestion of hepatic sinusoids and mononuclear cells infiltration close to blood vessel (Figure 3b) were occasionally observed. Cloudy swelling with condensation of the chromatin materials in the periphery of the nuclei and uneven nuclear membranes were detected (Figure 3c). Several studies were done on the genotoxicity of $P$. granantum and they found that in-vitro use of aqueous extract of $P$. granatum peel lead to apoptosis in human cells [56-59].The results of $P$. granatum peel extract tested on brine shrimp assay by Mehru et al. [59] which is the recommended cutoff point to detect cytotoxic activity. Tripathi and Singh [57] found no significant differences in snails after using various methods of extraction and different parts of the $P$. granatum plant. These finding may be attributed to the toxic effect of alkaloid content of some parts of $P$. granatum extract $[57,60]$.

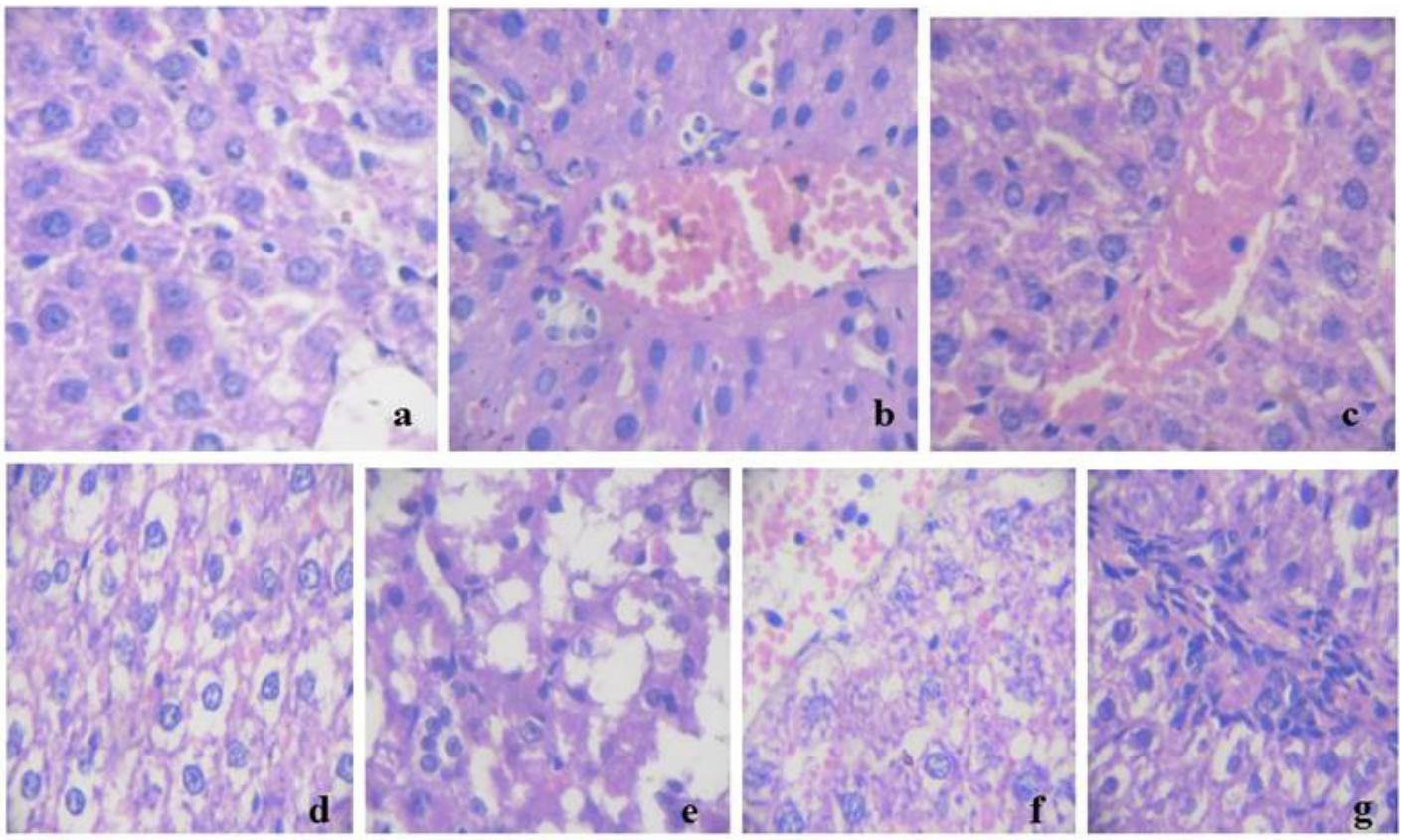

Figure 3: Liver section of rat treated with punica granatum peel aqueous extract stained with $\mathrm{H \& E}$.X400 showed (a) An apoptotic cells (b) Binucleated hepatocytes, pyknosis, congestion and dilatation of central vein. (c) Congested blood vessel with partially hemolysed RBCs. Photomicrograph of rat liver section treated with lead acetate concurrent with punica granatum peel aqueous extract stained with H\&E X400. showed (d\&e) loss of the normal architecture, hydropic degeneration and pyknotic nuclei with many small necrotic areas. (f) Diffuse necrosis of hepatocytes associated with vacuolation and hydropic degeneration and congested blood vessel. (g) Mononuclear cell infiltration.

Serum calcium level showed a significant decrease in pomegranate extract treated group compared to the control group (Table 1). Similar finding was explained by Nozire and Serpil [61], who stated that pomegranate rind contains tannins which proved to lower $\mathrm{Ca}$ absorption in rat [62], but on the other side, Abd Elmonem [63] reported that pomegranate has no significant effects on calcium. Aqueous extract of pomegranate peel treated group has no significant effects on urea and creatinine levels (Table 1). This finding is in disagreement with that reported by Abdel Moneim et al. [7], who stated that administration of pomegranate induced significant increase in urea levels. Unfortunately, rat kidney treated by punica granatum peel aqueous extract showed hyperemic glomerular tuft (Figure 4a) associated with hemorrhage (Figure 4b). Mild hemorrhage between degenerated renal tubules with few mononuclear cells infiltration was occasionally observed (Figure 4c). These results were disagreed with some previous 
results indicated that $p$. granatum extracts has a preventative effect on unilateral ureter obstruction-induced kidney damage in rats by reducing oxidative stress [64]. This contradiction between biochemical and histopathological results could be attributed to delay of clinical abnormalities and more than $75 \%$ of individual nephrons may have been lost before clinical detection of azotemia because the remaining nephrons undergo compensatory hypertrophy to maintain renal function [65].

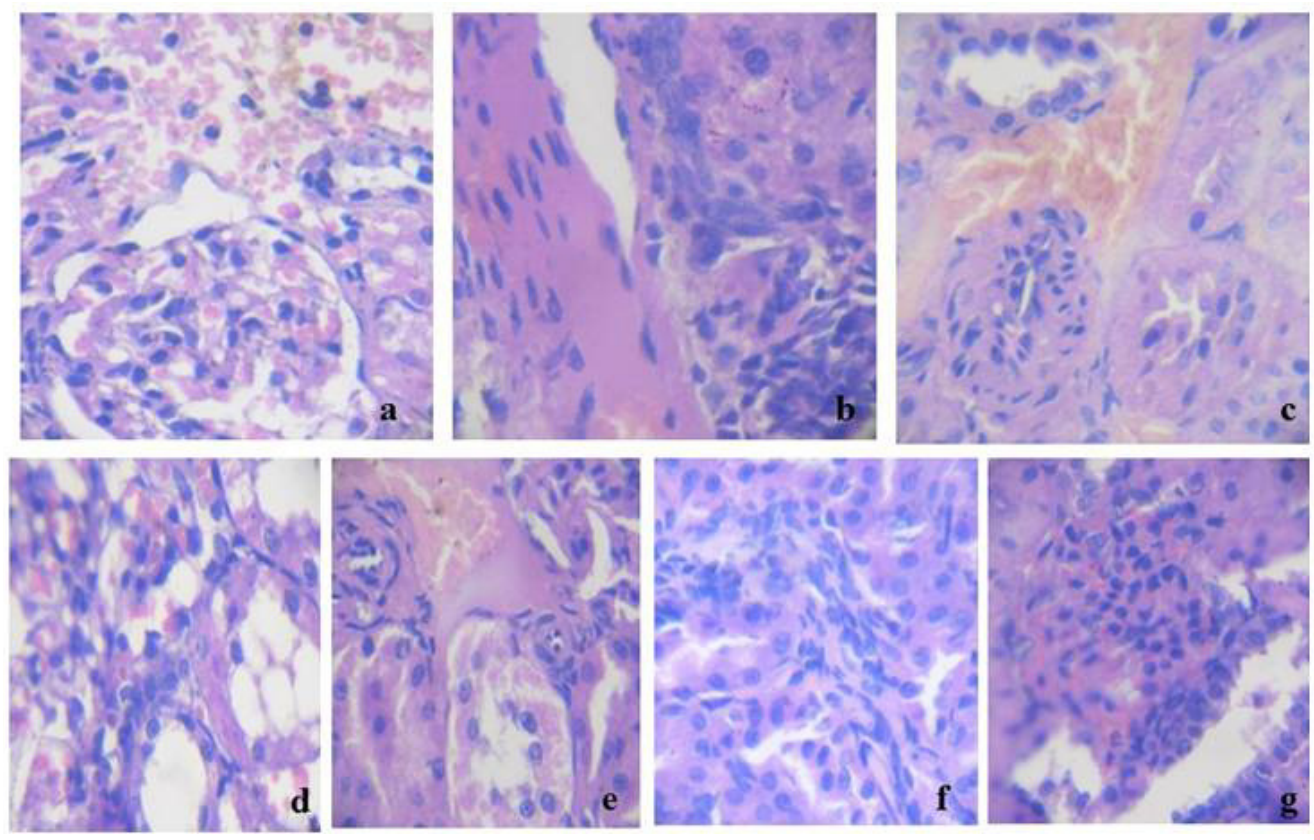

Figure 4: Kidney of rat treated by punica granatum peel aqueous extract stained with H\&E.X400 showed (a) Hyperemic glmerulie tuft, periglomerular necrosis associated with hemorrhage. (b) Mononuclear cells infiltration at thicked wall of blood vessel. (c) Extravasations of red blood cells between the degenerated renal tubules. Photomicrograph of rat kidney treated by lead acetate concurrent with punica granatum peel aqueous stained with H\&E X400 showed (d) Degeneration in the epithelial cells lining the renal tubule. (e) Extravasations of red blood cells between the degenerated renal tubules associated with hemorrhage. (f) Mononuclear cells infiltration. (g) Hyperemic glomerular tuft, hemorrhage, glomerulus hypercellularity and degeneration in the glomerular endothelium.

Most of biochemical parameters in serum of rats treated with both of lead and $P$. granatum aqueous extract showed significant improvement when compared with the serum of rats intoxicated with lead (Table 1). Histopathological findings in the liver of rats treated with both of lead acetate and $P$. granatum peel aqueous extract for 5 weeks showed hydropic degeneration, small focal necrotic areas (Figure 3d\&e) with hydropic degeneration, congestion of blood vessel (Figure 3f) and mononuclear cell infiltration (Figure 3g). Kidneys in our results showed degeneration in the epithelial lining of renal tubules (Figure 4d), mild focal intertubular hemorrhage (Figure 4e), mononuclear cells infiltration (Figure 4f) and hypercellularity of renal glumeoli (Figure $4 \mathrm{~g}$ ). Similar result was reported by Pedersen [66], who mentioned that, prolonged use of Punica granatum could damage the liver and might induce liver dysfunction. On the other hand, these findings are disagreement with El-Rashedy et al. [67], who reported that pomegranate playing an important role in curing obesity-induced fatty liver disease that attributed to its antioxidant capacity [68], due to its content of polyphenolic compounds [69], the protective effects against liver fibrosis and suppression of collagen synthesis [70].

In current study, serum cholesterol level showed a significant increase in all treated 
groups when compared with the control group. While other studies reported that pomegranate juice induced reduction of cholesterol level in diabetic human [71] and similar findings were reported using pomegranate aqueous extract in diabetic rat [72]. This apparent contradiction could be attributed to the difference in health condition of experimental animals used in respective studies. Regarding lead residues in tissues, they revealed accumulation in liver of lead treated group at level of $1.855 \pm 0.07 \mu \mathrm{g} / \mathrm{g}$ (table 1). Our findings are consistent with that of Suleman et al. [73], who stated that lead possessed a significant capability of bioaccumulation in tissues. Presence of lead in serum and liver of rats treated with $P$. granatum water extract (table 1) could be attributed to the presence of lead in pomegranate peel as reported by Hasan et al. [15].

Decline of lead residue to the level of $1.201 \pm 0.08 \mu \mathrm{g} / \mathrm{g}$ of rats treated with lead acetate with pomegranate aqueous extract may be attributed to increase lead entered into the rats' gut which promote redistribution of lead from soft tissues towards bone [74]. Although traditional and herbal medicine may promise opportunities in the field of treatment of various diseases, their safety must always be considered [75].

\section{Conclusion}

Lead permeation problem is considered a great public health trouble. Pomegranate peel water extract had deceptive improvement on the oxidative damage that induced by lead intoxication in rats. Further investigations are required to clarify its safety, chemical composition, toxicity and biological properties before being recommended as therapeutic herbal.

\section{Conflict of interest}

The authors declare no conflict of interest.

\section{References}

[1] Lead, W. I. (1995): Environmental Health Criteria 165. International Programme on Chemical Safety. Geneva: World Health Organization.

[2] Ercal, N.; Gurer-Orhan, H. and AykinBurns, N. (2001): Toxic metals and oxidative stress. Part I: mechanisms involved in metal-induced oxidative damage. Curr Top Med Chem, 1(6): 529539.

[3] Kasten-Jolly, J.; Heo, Y. and Lawrence, D.A. (2010): Impact of lead exposure on splenic factors. Toxicol Applied pharmacol, 247(2): 105-115.

[4] El-Neweshy, M.S. and El-Sayed, Y.S. (2011): Influence of vitamin C supplementation on lead-induced histopathological alterations in male rats. J Exp Tox Path, 63(3): 221-227.

[5] Dewanjee, S.; Sahu, R.; Karmakar, S. and Gangopadhyay, M. (2013): Toxic effects of lead exposure in Wistar rats: Involvement of oxidative stress and the beneficial role of edible jute (Corchorus olitorius) leaves. Food Chem Toxicol, 55:78-91.

[6] Flora, S.; Flora, G. and Saxena, G. (2006): Environmental occurrence, health effects and management of lead poisoning In: Casas, J.S., Sordo, J., editors-Lead chemistry, analytical aspects, environmental impact and health effects. Amsterdam, Netherland. Elsevier Science. PP:158-228.

[7] Abdel-Moneim, A.; Dkhil, M.A. and AlQuraishy, S. (2011): The potential role of flaxseed oil on lead acetate- induced kidney injury in adult male albino rats. Afr J Biochem, 10(8):1436-1451.

[8] Ibrahim, M.; Eweis, A.; El-Beltagi, S. and Abdel-Mobdy, E. (2012): Effect of lead acetate toxicity on experimental male albino rat. Asian Pac J Trop Biomed, 2(1): 41-46

[9] Jurczuk, M.; Brzóska, M.; and Moniuszko-Jakoniuk, J. (2007): Hepatic and renal concentrations of vitamins $\mathrm{E}$ and $\mathrm{C}$ in lead- and ethanol-exposed rats. An assessment of their involvement in the mechanisms of peroxidative damage. Food Chem Toxicol, 45(8):1478-1486.

[10] Franco, R.; Sánchez-Olea, R.; ReyesReyes, E.M. and Panayiotidis, M.I. (2009): Panayiotidis, Environmental toxicity, oxidative stress and apoptosis: menage a trois. Mutat Res Genet Toxicol Environ Mutagen, 674(1): 3-22. 
[11] Upasani, C.; Khera, A. and Balaraman, R. (2001): Effect of lead with vitamin E, $\mathrm{C}$ or spirulina on malondialdehyde dienes and hydroperoxides in rats. Indian J Exp Biol, 39(1): 70-74.

[12] Wang, Z.; Pan, Z.; Ma, H. and Atungulu , G. (2011): Extract of Phenolics From Pomegranate Peels. Open Food Sci J, 5: $17-25$

[13] Genena, D.M. and Agamy, N.F. (2017): effect of pomegranate juice and peel on antioxidant enzymes and lipid profile in carbon tetrachloride-induced hyperlipidemic rats. Int J Adv Res, 5(1): 1708-1714.

[14] Khalil, E.A. (2004a): A hepatoprotective effect of an aqueous extract of omegranate (Punica granatum L.) rind against acetaminop hen treated rats. Egypt J Hosp Med,16: 112-118

[15] Hasan, S.M.; Abou-Rawash, A.E.A. and Bekheet, M.S. (2016): Protective Role of an Aqueous Extract of Punica Granatum (Pomegranate) Peel on Lead-Induced anemia in Rats. AJVS,50 (1): 99-108

[16] Khalil, E.A. (2004b): Antidiabetic effect of an aqueous extract of Pomegranate (Punica granatum L.) peels in normal and alloxan diabetic rats. Egypt J Hosp Med, 16(1): 92-99.

[17] Suradkar, S.G.; Ghodasara, D. J.; Vihol, P.; Patel, J.; Jaiswal, V. and Prajapati, K.S. (2009): Haemato-Biochemical Alterations induced by lead acetate toxicity in Wistar Rats. Vet World, 2(11): 429-431.

[18] Doumas, B.T.; Bayse, D.D.; Carter, R.J.; Peters, T. and Schaffer, R. (1981): A candidate reference method for determination of total protein in serum. I. Development and validation. Clin Chem, 27(10):1642-1650.

[19] Webster, D. (1977): Albumin standards and measurement of serum albumin with bromochresol green. Clin Chem, 23:663666.

[20] Narayanan, S. (1982): Methodcomparison studies on immunoglobulins. Clin Chem, 28(7):1528-1531
[21] Price, C.P.; Spencer, K. and Whicher, J. (1983): Light-scattering immunoassay of specific proteins: a review. Ann Clin Biochem; 20(1):1-14.

[22] Reitman, S. and Frankle, S. (1957): A colorimetric method for determination of serum glutamic oxaloacetic and glutamic pyruvic transaminases. Am J Clin Path, 28(1):56-63

[23] Belfield, A. and Goldberg, D.M. (1971): Colorimetric determination of alkaline phosphatase activity. Enzyme, 12(5):561-568.

[24] Patton, G.J. and Crouch, S.R. (1977): Determination of urea (urease modified Berthelot reaction). Anal Chem, 49:464469.

[25] Husdan, H. and Rapoport, A. (1968): Estimation of creatinine by the Jaffe reaction. Clinical Chemistry, 14(3):222238.

[26] Fossati, P. and Medicci, R. (1987): International Symposium on Cholesterol Control and Cardiovascular Diseases: Prevention and Therapy. Milan, Italy. Apud Bayer Corporation, Diagnostic Division, Tarrytown, N.Y., CholesterolFast Color.

[27] Buege, J.A. and Aust, S.D. (1978): Microsomal lipid peroxidation. Methods Enzymol, 52:302-310.

[28] Dehpour, A.R., Essalat, M., Ala S., Ghazi- Khansari, M., and Ghafourifar, P. (1999): Increase by NO synthase inhibitor of lead-induced release of $\mathrm{N}$ acetyl- $\beta$-d-glucosaminidase from perfused rat kidney. Toxicol, 132:119125.

[29] Nussey, S.S. and Whitehead, S.A. (2001): Endocrinology: an integrated approach. BIOS Scientific.

[30] 30. Brown, A.A. and Taylor, A. (1995): Applications of a slotted quartz tube and flame atomic absorption spectrophotometer to the analysis of biological samples. Analyst, 110(6): 579582.

[31] Brown, A.A.; Halls, D.J. and Taylor, A. (1986): Atomic spectrometry update- 
clinical materials, foods and beverages. $\mathbf{J}$ Anal Atom Spect, 1(2): 29-44.

[32] 32. Mason C. F. (1991): Biology of freshwater pollution. 2nd ed. Harlow, Essex, England: Longman Scientific \& Technical; New York: Wiley.

[33] Bancroft, J.D. and Gamble, M. (2008): Theory and practice of histological techniques. Elsevier Health Sciences.

[34] Shalan, M.G.; Mostafa, M.S.; Hassouna, M.M.; El-Nabi, S.H. and El-Refaie, A. (2005): Amelioration of lead toxicity on rat liver with vitamin $\mathrm{C}$ and silymarin supplements. Toxicol, 206(1):1-15.

[35] Kaplan, M.M. and Reghetti, A. (1970): Induction for rat liver alkaline phosphatase: The mechanism of serum elevation in bile duct obstruction. J Clin Invest, 49(3): 508-516.

[36] El-Sokkary, G.H.; Abdel-Rahman, G.H. and Kamel, E.S. (2005): Melatonin protects against lead-induced hepatic and renal toxicity in male rats. Toxicol, 213(1):25-33.

[37] El-Sayed, M.F.; Abdel-Ghafar, S.K.; Adly, M.A.; Salim, A.A. and AbdelSamei, W.M. (2015): The Protective effects of DMSA and some vitamins against toxicity induced by lead in male Albino rats. J Basic Appl Zool, 71:60-65.

[38] Hamadouche, N.A.; Slimani, M. And Aoues, A. (2012): Beneficial effect administration of vitamin $\mathrm{C}$ in Amelioration of lead Hepatotoxicity. Not Sci Bio, 4(3):07-13.

[39] Zaki, M.S.; El Batrawy, N.; Fawzi, O.M. and Ataa, N.S. (2010): lead toxicity in bull. Report and Opinion,2(2):62-66

[40] Flood, J.F. and Morley, J.E. (1988): Effects of bombesin and gastrinreleasing peptide on memory processing. Brain Res, 460(2):314-322.

[41] Ikechukwu, I.C.; Ojareva, O.I.A.; Ibhagbemien, A.J.; Okhoaretor, O.F.; Oluwatomi, O.B.; Akhalufo, O.S.; Oluwagbenga, A.T. and Chigaekwu, M.N. (2012): Blood lead, calcium, and phosphorus in women with preeclampsia in Edo State, Nigeria. Arch Environ Occup Health, 67(3):163-169.

[42] Mogwasi, R., Getenga, Z., Nyambaka Hudson, R.W., Murungi, J., Okiambe, E. and Onyancha, E. (2013): Comparison of lead levels with calcium, zinc and phosphorus levels in human blood. Global J Pure Appl Chem Res, 1(1):4459.

[43] Kursula, P. and Majava, V. (2007): A structural insight into lead neurotoxicity and calmodulin activation by heavy metals. Acta Crystallogr Sect F: Struct Biol Cryst Commun, 63(8):653-656.

[44] Simons, T.J. (1986): Cellular interaction between lead and calcium. Br Med Bull, 42(4):431-434.

[45] Shier, D.; Butler, J. and Lewis, R. (2006): Hole's essentials of human anatomy and physiology. New York: McGraw-Hill.

[46] Pekcici, R.; Kavlakoğlu, B.; Yilmaz, S.; Şahin, M. and Delibaşi, T. (2010): Effects of lead on thyroid functions in lead-exposed workers. Central Eur J Med, 5(2):215-218.

[47] Singh, R.P.; Chidambara Murthy, K.N. and Jayaprakasha, G.K. (2002): Studies on the antioxidant activity of pomegranate (Punica granatum) peel and seed extracts using in vitro models. J Agri Food Chem, 50(1): 81-86.

[48] Arrak, J.K. (2010): Effect of Ellagic Acid Extracted from Pomegranate (Punica granatum L.) on Thyroid and Parathyroid Gland of Adult Rats Exposed to Lead Acetate. Kufa J Vet Med Sci,1:1.

[49] Qu, W.; Diwan, B.A.; Liu, J.; Goyer, R.; Horton, J. and Cherian, M. (2002): The metallothionein-null phenotype is associated with heightened sensitivity to lead toxicity and an inability to form inclusion bodies. Am J Pathol, 160(3):1047-1056.

[50] El-Nekeety, A.A.; El-Kady, A.A.; Soliman, M.S.; Hassan, N.S. and AbdelWahhab, M.A. (2009): Protective effect of Aquilegia vulgaris (L.) against lead 
acetate-induced oxidative stress in rats. Food Chem Toxicol, 47(9): 2209-2215.

[51] 51. Noda, Y.; Kaneyuki, T.; Mori, A. and Packer, L. (2002): Antioxidant activities of pomegranate fruit extract and its anthocyanidins: delphinidin, cyanidin, and pelargonidin. J Agric Food Chem, 50(1): 166-171.

[52] Sudheesh, S. and Vijayalakshmi, N. (2005): Flavonoids from Punica granatum- potential antiperoxidative agents. Fitoterapia, 76(2):181-186.

[53] 53. Seeram, N.P.; Adams, L.S.; Hennig, S.M.; Niu, Y.; Zhang, Y.; Nair, M.G. and Heber, D. (2005): In vitro antiproliferative, apoptotic and antioxidant activities of punicalagin, ellagic acid and a total pomegranate tannin extract are enhanced in combination with other polyphenols as found in pomegranate juice. J. Nutr Biochem, 16(6): 360-367.

[54] Kaur, G.; Jabbar, Z.; Athar, M. and Alam, M.S. (2006): Punica granatum (pomegranate) flower extract possesses potent antioxidant activity and abrogates Fe-NTA induced hepatoxicity in mice. Food Chem Toxicol,44(7): 984-993.

[55] Khalil E.A.M. (2004): Biochemical and histopathological changes in male albino rats treated with overdose of an aqueous extract of pomegranate (Punica granatum L.) pericarps. Egypt J Hosp Med,16:132139

[56] Setheetham, W. and Ishida, T. (1995): Study of genotoxic effects of antidiarrheal medicinal herbs on human cells in vitro. Southeast Asian J Trop Med Public Health, 26:306-310.

[57] Tripathi, S.M. and Singh, D.K. (2000): Molluscicidal activity of Punica granatum bark and Canna indica root. Braz J Med Biol Res, 33(11):1351-1355.

[58] Simionatto, E.; Porto, C.; Silva, U.F.; Squizani, A.; Dalcol, I.I. and Morel, A.F. (2005): Composition and antimicrobial activity of the essential oil from Aloysia sellowii. J Braz Chem Soc, 16(6B):14581462.

[59] Mehru, N., Rathinam, X., Subramaniam, S., Aiyalu, R., Sreenivasan, S., and
Reenivasan, S. (2008): Antimicrobial activity and toxicity of Punica granatum 1., peel. J Appl Biol Sci, 2(3):57-59.

[60] Ferrara, L.; Schettino, O.; Forgione, P.; Rullo, V. and Di Gennaro, S. (1989): Identification of the root of Punica granatum in galenic preparations using TLC. Boll Soc Ital Biol Sper, 65(5):385390.

[61] Nozire, O. and Serpil, D. (1993): Valuation of the pomegranate (Punica granatumL.) peels from the stand point of pharmacy. Ankara Ecz Fak Deg, 22:121-122.

[62] Chang, M.C.; Bailey, J.W. and Collins, J.L. (1994 ): Dietary tannins from cowpeas and tea transiently alter apparent calcium absorption but not absorption and utilization of protein in rats. J Nutr, 124(2):283-288.

[63] Abd Elmonem, H.A. (2014): Assessment the Effect of Pomegranate Molasses against Diazinon Toxicity in Male Rats. J Environ Sci Toxicol Food Technol, 8(2):135-141.

[64] Otunctemur, A.; Ozbek, E.; Cakir, S.S.; Polat, E.C.; Dursun, M.; Cekmen, M.; Somay, A. and Ozbay, N. (2015) : Pomegranate extract attenuates unilateral ureteral obstruction induced renal damage by reducing oxidative stress. Urol Ann,7(2):166

[65] Thrall, M. A.; Campbell, T. W.; De Nicola, D.; Fettman, M. J.; Lassen, E. D.; Rebar, A. and Wieser, G. (2004): Veterinary Hematology and Clinical Chemistry. Page 303 Lippincott Williams \& Wilkins., A walters Kluwer Company., Philadelphia, Baltemore, New York, London.

[66] Pederson, M. (1998): Nutritional Herbology A Reference Guide to Herbs Wendell W. Whitman Company.

[67] El-Rashedy, A.; Saeed, K.; Hossam ElDin, O. and Gaber, M. (2011): Protective Role of Pomegranate on Fatty Liver in Obesity: An Experimental Chemical \& Histopathological Study. Egypt J Hosp Med, 43:162-172. 
[68] Khalil E.A. (2004b): A hepatoprotective effect of an aqueous extract of pomegranate (Punica granatum L.) rind against acetaminop hen treated rats. Egypt J Hosp Med,16:112-118

[69] Agha, F.E.; Hassannane, M.M.; Omara, E.A.; Hasan, A.M. and El-Toumy, S.A. (2013): Protective Effect of Punica granatum Peel Extract Against Pentachlorophenol-Induced Oxidative Stress, Cytogenetic Toxicity and Hepatic Damage in Rats. Aust J Basic Appl Sci,7(2): 853-864.

[70] Wei, X.L.; Fang, R.T.; Yang, Y.H.; Bi, X.Y.; Ren, G.X.; Luo, A.L.; Zhao, M. and Zang, W.J. (2015): Protective effects of extracts from Pomegranate peels and seeds on liver fibrosis induced by carbon tetrachloride in rats. BMC Complement Altern Med, 15(1):389.

[71] Esmaillzadeh, A.; Tahbaz, F.; Gaieni, I.; Alavi-Majd, H.; and Azadbakht, L. (2004): Concentrated pomegranate juice improves lipid profiles in diabetic patients with hyperlipidemia. J Med Food, 7(3):305-308.
[72] Bagri, P.; Ali, M.; Aeri, V.; Bhowmik, M. and Sultana, S. (2009): Antidiabetic effect of Punica granatum flowers: effect on hyperlipidemia, pancreatic cells lipid peroxidation and antioxidant enzymes in experimental diabetes. Food Chem Toxicol, 47:50-54.

[73] Suleman, M.; Khan, A.A.; Hussain, Z.; Zia, M.A.; Roomi, S.; Rashid, F.; Iqbal, A. and Ishaq, R. (2011): Effect of lead acetate administered orally at different dosage levels in broiler chicks. Afr J Environ Sci Technol, 5(12):1017-1026

[74] Smith, M.O. George, L.W. (2009): Disease of the nervous system. In: Large animal internal medicine, $4^{\text {th }}$ ed., ed. Smith B, pp. 1032-1035. Mosby, St Louis, MO.

[75] Jahromi, S.B.; Pourshafie, M.R.; Mirabzadeh, E.; Tavasoli, A.; Katiraee, F.; Mostafavi, E. and Abbasian, S. (2015): Punica granatum Peel Extract Toxicity in Mice. Jundishapur J Nat Pharm Prod, 10(4). 


$$
\begin{aligned}
& \text { الملخص العربي المبي المي } \\
& \text { تأثير المستخلص المائي لقشر الرمان علي التلف التأكسدي من التسمم بالرصاص في الفئران. }
\end{aligned}
$$

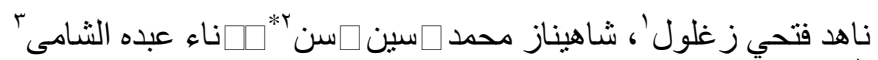

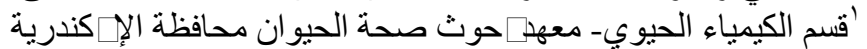

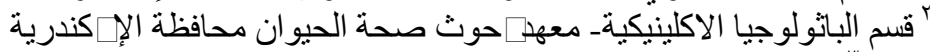

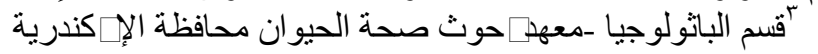

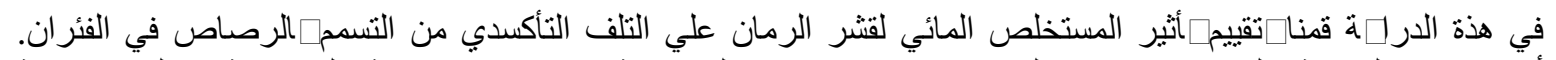

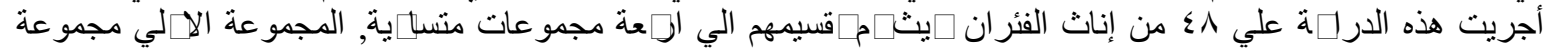

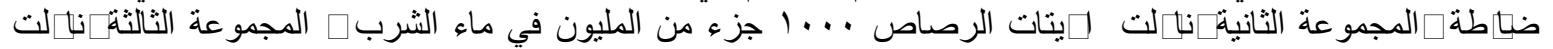

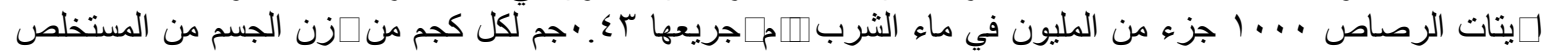

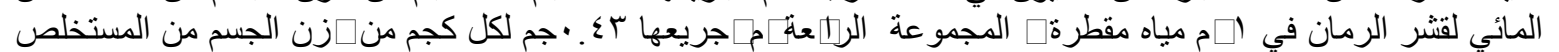

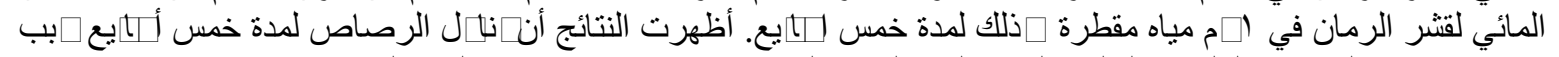

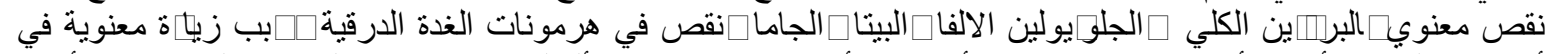

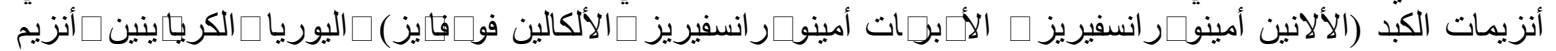

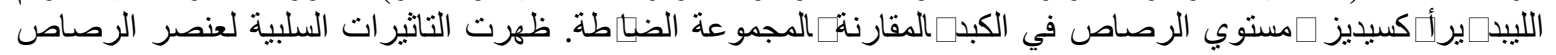

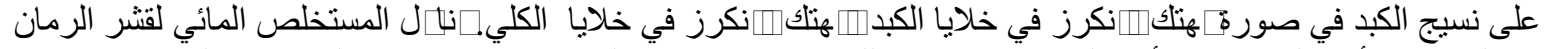

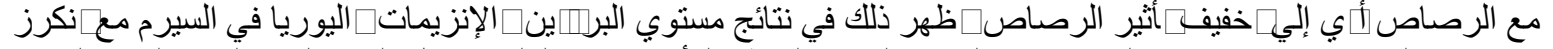

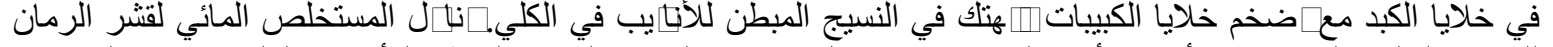

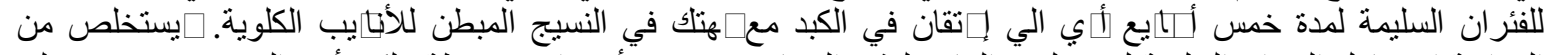

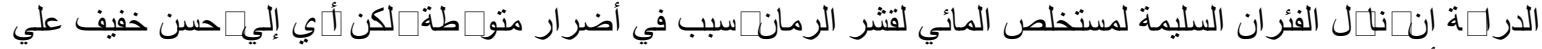

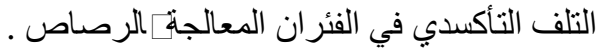

